\title{
RESEARCH FOR ALL
}

RESEARCH

The open-access journal for public engagement with research

ISSN 2399-8121 (Online)

Journal homepage:

https://www.uclpress.co.uk/pages/research-for-all

\section{What inspired my thinking to create UCL EDUCATE?}

Rose Luckin iD

\section{How to cite this article}

Luckin, R. (2021) 'What inspired my thinking to create UCL EDUCATE?'. Research for All, 5 (1), 16-18. https://doi.org/10.14324/RFA.05.1.03

Submission date: 18 August 2020

Acceptance date: 28 October 2020

Publication date: 16 February 2021

\section{Peer review}

This article has been through editorial review.

\section{Copyright}

(C) 2021 Luckin. This is an open-access article distributed under the terms of the Creative Commons Attribution Licence (CC BY) 4.0 https://creativecommons.org/licenses/by/4.0/, which permits unrestricted use, distribution and reproduction in any medium, provided the original author and source are credited.

\section{Open access}

Research for All is a peer-reviewed open-access journal. 


\title{
What inspired my thinking to create UCL EDUCATE?
}

\author{
Rose Luckin* - UCL Institute of Education, UK
}

I had been working as an academic with educational technology companies for several years, and the gradual realization that a project was needed to connect three communities - the people who develop educational technology, the people who use technology for teaching and learning, and the researchers who understand the evidence about what works - emerged from this long experience of working in the sector. I had been leading substantial projects with commercial partners, educators and learners, but had still not been able to fully connect these communities. This disconnect between the people who were building the technology and the people who were using the technology (such as teachers, learners, trainers and educators) was the key factor in deciding to seek the funding to create EDUCATE. Back in 2013, I brought together a group of people from education and technology companies, as well as from academia, to discuss how we could better connect these three key communities.

Later, the idea of the golden triangle emerged, the key elements of which are the three points that represent each community, followed by the realization that the gold was the evidence - it was this evidence that needed to be strengthened through closer collaboration between the community members. Over the next couple of years, I had conversations with various different organizations to try to pursue funding to progress the idea, but with no success. I was convinced that it was the small companies that would benefit most from working with the UCL Institute of Education academic team because these companies could not afford to do their own research. These small companies struggled to engage with both research knowledge and researchers, and also to connect with educators. Then, the European Regional Development Fund call was published, and one of its key priorities was a perfect fit: connecting research and universities with small and medium-sized enterprises (SMEs). The project was successful in being funded and, as a result, the EDUCATE team has been able the enact the golden triangle and has created something of value that people can now see.

EDUCATE is strengthening entrepreneurship within the educational technology (edtech) sector by putting the educational need that is being addressed by each technology product or service at the heart of their programme. As the entrepreneur is designing, developing, applying and scaling their technology, EDUCATE ensures that the educational need is at the heart of everything. EDUCATE supports the generation of evidence for efficacy and effectiveness of emerging technologies by changing the expectation, and the dialogue, around evidence and advocacy, so that every entrepreneur sees its generation as an important part of their role. It may be the case that in the future, as the companies grow, they do employ other people to generate their research, but they will do this with an understanding of research and evidence that they did not have before. Also, even if someone else conducts the research, the 
entrepreneurs will know enough to ensure that it will be done to the right standards because the entrepreneurs will themselves understand what the right standards are. Along the way, a more sophisticated conversation emerges about what it means to say, 'does it work? (or not?)', but also the SMEs transition to an understanding that to answer that question, they cannot just commission a study from an external research organization. Doing research needs to be at the heart of the business right from the outset - the collection of data and evidence to be able to validate the impact of the products should be a driver for the business.

The best approach for edtech entrepreneurs and educators to learn more about relevant evidence is to make a concerted effort to educate themselves about what constitutes appropriate evidence for efficacy and effectiveness in education, which is the heart of the EDUCATE approach. The opportunities for generating evidence are huge, but the SMEs have to understand what is evidence, what kind of evidence matters, and how it maps to whatever their product or service is trying to achieve educationally.

In addition, the edtech developers can also maintain their evidence collection by developing a 'research mindset' that means that at every opportunity they are seeing, and acting on, the potential data that they could be collecting. They understand how to analyse data, and how that informs whatever the business is doing. It is not enough to develop this mindset in one member of the company it is important to make sure that, somehow, it spreads throughout the business. My advice to entrepreneurs who are working to incorporate research findings into their products or service is to start by developing the theory of change and the associated logic model, and then to generate the evidence to challenge the underlying assumptions. The EDUCATE research training teaches entrepreneurs how to engage with existing research with a more critical eye. It is because they understand better what rigorous means - what good evidence is - that they can see better how it is or is not relevant to their business.

EDUCATE's own impact has been assessed using various metrics. First, the way in which EDUCATE has operationalized the notion of the golden triangle. Second, rigorous evidence of how that has been operationalized through the number of companies engaged with the programme ( 252 to date) - and the enthusiasm of the companies for the programme and its marks of success, the 'EdWards' (the EDUCATE programme's mark of an enterprise's engagement with research evidence). Third, from the way that the EDUCATE accelerator is now able to become a whole new commercially viable business through its global digital platform and the investment fund which is the new venture.

Over the next five years, my vision for EDUCATE is to offer the programme to the world, with the overarching vision to drive the design of better educational technology and to enable educators to apply that educational technology in a way that meets the key educational challenges that they are facing. And the same for learners. So, it is about the development of better educational technology services and products, but it is also about enabling the people who use those products or services, whether they are educators learners, students, trainers - whoever they are - to understand how to leverage that technology to meet the key educational challenges that they face, and through doing that, to create a better marketplace, a more informed marketplace. And, therefore, hopefully to lead to better learning in the end. 
This paper is published as part of a collection of pieces about the UCL EDUCATE project. The papers are:

De Ossorno Garcia, S. and Doyle, L. (2021) 'The mentoring relation as an interpersonal process in EDUCATE: A qualitative case study of mentor-mentee perspectives'. Research for All, 5 (1), 19-35. https://doi.org/10.14324/RFA.05.1.04.

Luckin, R. (2021) 'What inspired my thinking to create UCL EDUCATE?'. Research for All, 5 (1), 16-18. https://doi.org/10.14324/RFA.05.1.03.

Morrison, M., Blake, C., Embleton-Smith, F., Gosiewski, J. and Zvesper, J. (2021) ‘Pre-emptive intervention and its effect on student attainment and retention'. Research for All, 5 (1), 36-51. https://doi.org/10.14324/RFA.05.1.05.

Rogers, E. and Weatherby, K. (2021) 'Developing Little Bridge as an evidence-informed English language learning platform for 6-12 year olds'. Research for All, 5 (1), 52-66. https://doi.org/10.14324/RFA.05.1.06.

\section{Notes on the contributor}

Rose Luckin is Professor at UCL Knowledge Lab, UCL Institute of Education, UK, with a background in artificial intelligence and education. Rose is also Founder of EDUCATE, which runs a research accelerator for educational technology start-ups in London and has a focus on artificial intelligence. Rose co-founded the Institute for Ethical Al in Education, and she was named on the Seldon List 2017 as one of the 20 most influential people in education. 